\title{
Arterial oxygenation and mortality in patients admitted to intensive care following out-of-hospital cardiac arrest
}

\author{
R Ahmed*, L Paton, P Stenhouse, A Davidson, A Mackay \\ From ESICM LIVES 2015 \\ Berlin, Germany. 3-7 October 2015
}

\begin{abstract}
Intr
The effects of hyperoxia at a cellular level are well known, with formation of free radical species causing reactive damage. It has previously been shown that hyperoxia is associated with increased mortality in patients resuscitated from cardiac arrest [1]. However, hypoxia is likewise deleterious to outcomes in this patient cohort.
\end{abstract}

\section{Objectives}

We sought to examine whether mortality varies with arterial oxygenation in the first 24 hours after admission to our intensive care unit (ICU) following out of hospital cardiac arrest (OOHCA).

\section{Methods}

This was a retrospective, consecutive case series of patients admitted to the ICU at the Victoria Infirmary, Glasgow following OOHCA over a 15 year period between 1999 and 2014. Patients were identified and characterised using the WardWatcher ${ }^{\mathrm{TM}}$ database. Three subgroups were generated based on the arterial partial pressure of oxygen $\left(\mathrm{P}_{\mathrm{a}} 02\right)$ provided as part of severity scoring: hyperoxia was defined as $\mathrm{P}_{\mathrm{a}} 02>15$, normoxia as $\mathrm{P}_{\mathrm{a}} 0210-15$ and hypoxia as $\mathrm{P}_{\mathrm{a}} 02<10 \mathrm{kPa}$. Hospital mortality was the primary outcome measure and statistical significance was assessed using Fisher's exact test.

\section{Results}

There were 124 patients (73 men, 58.9\%) with a median age of 64 years (IQR 52-70 years) admitted following OOHCA. For the 97 patients with complete severity scoring, the median APACHE II score was 31 (IQR 24-35) and
Table 1 Prevalence \& mortality in art. oxygenation subsets.

\begin{tabular}{lll}
\hline & Number (\%) of patients & Hospital mortality \\
\hline Hyperoxia & $71(68.9 \%)$ & $74.6 \%$ \\
\hline Normoxia & $20(19.4 \%)$ & $75.0 \%$ \\
\hline Hypoxia & $12(11.7 \%)$ & $83.3 \%$ \\
\hline
\end{tabular}

mortality prediction $80.3 \%$ (IQR $59.4 \%-87.9 \%$ ). Survival to hospital discharge was achieved in 29 patients (23.4\%), yielding a standardised mortality ratio of 0.95 . Median hospital length of stay was 16 days (IQR 8-27 days). Data on arterial oxygenation were available for 103 patients.

There was no statistically significant difference in hospital mortality between groups ( $\mathrm{P}=1.0$ for hyperoxia vs. normoxia; $\mathrm{P}=0.68$ for normoxia vs. hypoxia).

\section{Conclusions}

We demonstrated survival to hospital discharge in almost a quarter of patients admitted to ICU post-OOHCA. Despite international resuscitation guidelines to the contrary [2], a significant proportion of our patients continue to be exposed to hyperoxia. However, there is no evidence that arterial oxygenation levels impact outcomes in our unit.

\section{Published: 1 October 2015}

\section{References}

1. Kilgannon $\mathrm{JH}$, Jones $A E$, Shapiro $\mathrm{NI}$, et al: Association between arterial hyperoxia following resuscitation from cardiac arrest and in-hospital mortality. Journal of the American Medical Association 2010, 303:2165-71.

2. Nolan JP, Soar J, Zideman DA, et al: European Resuscitation Council Guidelines for Resuscitation: Executive summary. Resuscitation 2010, 81:1219-76. 
doi:10.1186/2197-425X-3-S1-A204

Cite this article as: Ahmed et al: Arterial oxygenation and mortality in patients admitted to intensive care following out-of-hospital cardiac arrest. Intensive Care Medicine Experimental 2015 3(Suppl 1):A204.

\section{Submit your manuscript to a SpringerOpen ${ }^{\mathcal{O}}$ journal and benefit from:}

- Convenient online submission

- Rigorous peer review

- Immediate publication on acceptance

- Open access: articles freely available online

- High visibility within the field

- Retaining the copyright to your article

Submit your next manuscript at $\gg$ springeropen.com 